\title{
Effect of gonadotrophin dose on oocytes yield and quality and embryonic development in Super ovulated mice
}

\author{
Samir A. M. Zaahkouk ${ }^{1}$, Ahmed S. Abdon², Ahmed M. Al-Atrash ${ }^{3}$, Omaima M. Kandil'2, \\ Amal A. A. Ammar ${ }^{4}$, Asmaa A. M. Yones ${ }^{4}$ \\ ${ }^{1}$ Faculty of science, Al-Azhar University. \\ ${ }^{2}$ Reproduction and Artificial Insemination, Veterinary Research Division, National Research Center. \\ ${ }^{3}$ Medical Administration, Nuclear Materials Authority. \\ ${ }^{4}$ Medical and Radiation Research Dept., Nuclear Materials Authority, Cairo, Egypt
}

\begin{abstract}
Background: Hormonal control for multiple follicular growths in IVF program was directed toward maximizing the yield of fertilizable oocytes, enhance successful implantation and improve early embryonic development.
\end{abstract}

Aim: The effect of different doses of urinary human menopausal gonadotropin (U-hMG) in superovulation regimen was studied.

Materials and Methods: Four groups of immature female mouse were sequentially injected by 5 IU, 10 IU, $15 \mathrm{IU}$ and $20 \mathrm{IU}$ of U-hMG followed by injection of $15 \mathrm{IU}$ human chorionic gonadotropin (hCG) for all groups. Mature cumulus oocytes complexes (COCs) were collected 12 hours later then the grading of cumulus cell expansion and oocytes maturity was determined. In vitro fertilization for mature oocytes was done by using epididymal sperm, the embryonic development was followed up till the blastocyst stage. Results: Results demonstrated that the super ovulatory response in immature mice increased with increasing dose of hMG. 15 IU U-hMG was the optimal dose that gave maximum number oocytes with higher maturation rate,minimum degeneration rate and support embryonic development.

Conclusion: $15 \mathrm{IU}$ is the optimal dose for induction of superovulation and support in vitro embryo developmentin immature female mice.

Keywords: Immature mice, HMG dose, Maturation rate, Cleavage rate, Embryo development.

\section{Introduction}

Superovulation is a technique used to produce a large number of embryos developmentally synchronized $^{[1]}$. It is employed for protocols such as embryo transfer ${ }^{[2]}$,embryonic stem (ES) cell production $^{[3]}$, transgenic animals ${ }^{[4]}$, and to develop animal models of human diseases [5]. Superovulation protocols based on gonadotrophic hormones have been standardized in species such like mouse ${ }^{[3]}$, pig ${ }^{[6]}$, cattle ${ }^{[7]}$, sheep ${ }^{[2]}$ and goat ${ }^{[8]}$, and the quality of the embryos produced appears to be satisfactory.

Mouse is the most commonly used animal model in reproductive research for obtaining mature oocytes or for investigating pre implantation embryo development. In such experiments, it is possible to test different reproductive techniques and infertility treatment programs ${ }^{[9]}$ and to determine the effects of potentially toxic materials on the oocytes or embryos ${ }^{[10,11]}$. In this respect a great number of ova/embryos is needed and therefore the number of mice required for a given experiment increases. However, in recent years an increasing interest in animal care and rights has arisen, limiting the use of laboratory animals in experimental procedures. Therefore, different superovulation with gonadotrophins regimen are widely performed to reduce the number of mice used in experiments, without reducing the accuracy of results. In mice, 8 to 10 ova are extruded by copulation-induced spontaneous ovulation ${ }^{[12]}$. This number can be substantially increased to 40 to 60 ova by using superovulation protocols [13]. However, the efficacy of exogenous stimulation varies with the strain, age, nutritional status and health, breeding-housing conditions of a female mouse, and the dose of administered gonadotrophins $[14,15]$. Therefore these factors that influence the number and quality of super ovulated eggs must be optimized for any given strain of mouse. The program for superovulation using human menopausal gonadotropin needs to be standardized. According to our knowledge there are no literatures on the effect of dose of human chorionic gonadotropin on development of 
Effect of gonadotrophin dose on oocytes yield and quality and embryonic development...

mouse embryos using and in vitro fertilization technique. Therefore, the current study was undertaken to evaluate the effect of three different doses of $\mathrm{hMG}$ on maturation, in vitro fertilization rates and the subsequent embryo development in Balb C mouse.

\section{Materials and methods Experimental animals}

In this study, female Balb $C$ mice of age 4-6 weeks were purchased from VACSERABiological and Vaccine Production Holding Co., Egypt). The mice were kept for two weeks in the Animals' lab at standard conditions, i.e., temperature of 23 to $25{ }^{\circ} \mathrm{C}$, humidity of 50 to $55 \%$, a 12-hour light cycle, and easy access to food and water for compatibility with the environment. The mice were divided randomly into four groups of equal numbers, 1) First group were injected with 5 IU urinary human menopausal gonadotropin (hMG); 2) Second group were injected with $10 \mathrm{IU}$ hMG; 3) Third group were injected with $15 \mathrm{IU}$ hMG; and 4) Fourth group were injected with $20 \mathrm{IU}$ hMG. Then all groups were injected with15 IU human chorionic gonadotropin (hCG) 48 hours later.

\section{Oocyte collection}

For the induction of oocyte development and reproduction in each mouse, Group (1):female mouse were injected intraperitonealy i.p. with 5 IU urinary hMG hormone (Merional, IBSA Farmaceutici Italia). Group (2): female mouse were injected i.p. with $10 \mathrm{IU}$ hMG. Group (3):female mousewere injected i.p. with 15 IU hMG. Group (4):female mouse were injected i.p. with $20 \mathrm{IU}$ hMG. For the purpose of inducing the ovulation process, 48 to 50 later $15 \mathrm{IU}$ of human chorionic gonadotropin (hCG), Chorimon, IBSA Farmaceutici Italia) were injected i.p in all groups. Twelve hours prior to the isolation of oocytes, the $100 \mu \mathrm{l}$ of Human tubal fluid (HTF)supplemented with $4 \mathrm{mg} / \mathrm{ml}$ bovine serum albumin (BSA) were dropped in $35 \mathrm{~mm}$ culture plate (Nun, Nunclon Denmark) and covered with mineral oil and kept in $\mathrm{CO}_{2}$ incubator for equilibration. On the day of oocytes isolation (12 hours after hCG hormone injections) the female mice were killed by neck beads' displacement, and the set of eggs and cumulus cells were collected from the ampulla of the uterine tubes of both sides and placed into the Petri dish containing HTF that had earlier been equilibrated in $\mathrm{CO}_{2}$ incubator for $12 \mathrm{~h}$.

\section{Sperm collection}

In order to collect sperm, cauda epididymis tail was dismembered and put into a Petri dish containing HTF in vitro that had already been equilibrated in $\mathrm{CO}_{2}$ incubator for $12 \mathrm{~h}$. Then, cauda epididymis were cut into small pieces and were placed for 1 hour inCO ${ }_{2}$ incubator (Class 100 Thermo Co., Germany) at $37{ }^{\circ} \mathrm{C}$ under 5\% $\mathrm{CO}_{2}$ for induction of capacitation.

\section{In Vitro Fertilization (IVF)}

One to two millions capacitated spermatozoa was added to drops containing oocytes. Oocytes coincubated with capacitated spermatozoa were placed in $\mathrm{CO}_{2}$ incubator for 4 to $5 \mathrm{hr}$. Then, the oocytes likely of insemination were transferred to a Petri dish containing $100 \mu 1$ drops of Potassium Simplified Optimized medium (KSOM) and covered with mineral oil. Oocytes were finally transferred to the fifth in the middle of the Petri dish after being washed in four side drops. Twenty-four hours after insemination, the number of two cell (and probably four-cell) embryos were counted and recorded by a stereomicroscope (Zeiss Co., Germany). Monitoring the embryo development was to blastocyst stage was recorded on Day-4 after IVF. Grading of embryo

The morphology of two blastomer embryos was divided into four Grades of A, B, C, and D (14). Grade A with equal blastomers, round, with no fragmentation, smooth cytoplasm, and bright yellow zona; Grade B with slightly different blastomers in size, up to $10 \%$ fragmentation with granules in cytoplasm; Grade $\mathrm{C}$ with unequal blastomers, up to $50 \%$ fragmentations and large granules and vacuoles in cytoplasm; and Grade D with blastomers of unequal size, extreme fragmentation, with dark and large granules and presence of vacuoles in cytoplasm.

\section{Statistical analysis}

Oocytes yield was analyzed by one-way ANOVA. While COCS expansion, maturation rate, degeneration rate, fertilization rate and embryonic development were tested for 
significance using the $X^{2}$ chi-square analysis. A value of $\mathrm{P}<0.05$ was regarded as indicative of statistical significance.

\section{Results}

Oocytes yield and nuclear maturation rate

The effect of different doses of hMG on superovulationresponse in mice as indicated by oocytes yield, quality and the subsequent embryo development after in vitro fertilization is demonstrated in Table 1 and Figure 1. The obtained results showed that super ovulatory response in terms of number of oocytes recovered was significant $(\mathrm{P}<0.01)$ higher by using $20 \mathrm{IU}$, $15 \mathrm{IU}$ and $10 \mathrm{IU}$ hMG than when using $5 \mathrm{IU}$ hMG superovulation regimen. A significantly $(\mathrm{P}<0,01)$ higher number of oocytes were collected by using the $20 \mathrm{IU}$ hMG dose than $10 \mathrm{IU}$ hMG regimen. While no significant difference in number of oocytes recovered after using $15 \mathrm{IU}$ hMG and 20 IU hMG doses. The percentage of cumulus oocytes complexes (COCs) with full cumulus cell expansionwas significantly $(\mathrm{P}<0.001)$ higher after induction of superovulation with $20 \mathrm{IU}$ or $15 \mathrm{IU}$ than by using $5 \mathrm{IU}$ hMG or $10 \mathrm{IU}$ hMG. Maturation rate as indicated by the percentage of oocytes extruding the first polar body $\left(1^{\text {st }}\right.$ polar body) was significantly $(\mathrm{P}<0.05)$ when using 15 IU hMG than $20 \mathrm{IU}$ and highly significant $(\mathrm{P}<0.001)$ than $5 \mathrm{IU}$ hMG or $10 \mathrm{IU}$ HMG. Also $20 \mathrm{IU}$ hMG gave significantly $(\mathrm{P}<0.001)$ higher maturation rate than $5 \mathrm{IU} \mathrm{hMG}$ or $10 \mathrm{IU}$ hMG. No significant difference in maturation rate was detected after using $5 \mathrm{IU}$ hMG or $10 \mathrm{IU}$ hMG for induction of superovulation in female mice $(\mathrm{P}=0.571)$.

In addition, the number of degenerated oocytes was significantly $(\mathrm{P}<0.001)$ lower in group of female mice superovulated by using $15 \mathrm{IU}$ hMG than that treated with $5 \mathrm{IU}$ hMG, $10 \mathrm{IU}$ hMG or20 IU. No significant difference was detected in the percentages of degenerated oocytes after induction of super ovulation using $5 \mathrm{IU}$ hMG, 10 IU hMG or 20 IU hMG.

Table 1: Effect of different dose of hMG used for induction of superovulation in mice on oocytes yield, cumulus cell expansion and nuclear maturation and oocytes degeneration.

\begin{tabular}{|c|c|c|c|c|c|}
\hline $\begin{array}{c}\text { HMG } \\
\text { dose }\end{array}$ & Ovaries No. & $\begin{array}{c}\text { Oocytes No. } \\
\text { Mean } \pm \text { S.E }\end{array}$ & $\begin{array}{c}\text { Full COCs } \\
\text { Expansion }\end{array}$ & MII & Degenerated \\
\hline $5 \mathrm{IU}$ & 60 & $311^{* *} 51.8 \pm 5.42$ & $162(52 \%)$ & $135(43.4 \%)$ & $20(6.4 \%)$ \\
\hline $10 \mathrm{IU}$ & 60 & $707^{*} 117.8 \pm 4.48$ & $386(54.6 \%)$ & $329(46.5 \%)$ & $38(5.4 \%)$ \\
\hline $15 \mathrm{IU}$ & 60 & $794132.2 \pm 5.93$ & $703(88.5 \%)^{* *}$ & $732(92.1 \%)^{* *}$ & $11(1.38 \%)^{*}$ \\
\hline $20 \mathrm{IU}$ & 60 & $876146 \pm 3.9$ & $718(84.9 \%)^{* *}$ & $692(78.9 \%)^{*}$ & $70(7.99 \%)$ \\
\hline
\end{tabular}

*Significantly differ at $\mathrm{P}<0.05, * *$ significantly differ at $\mathrm{P}<0.01$.

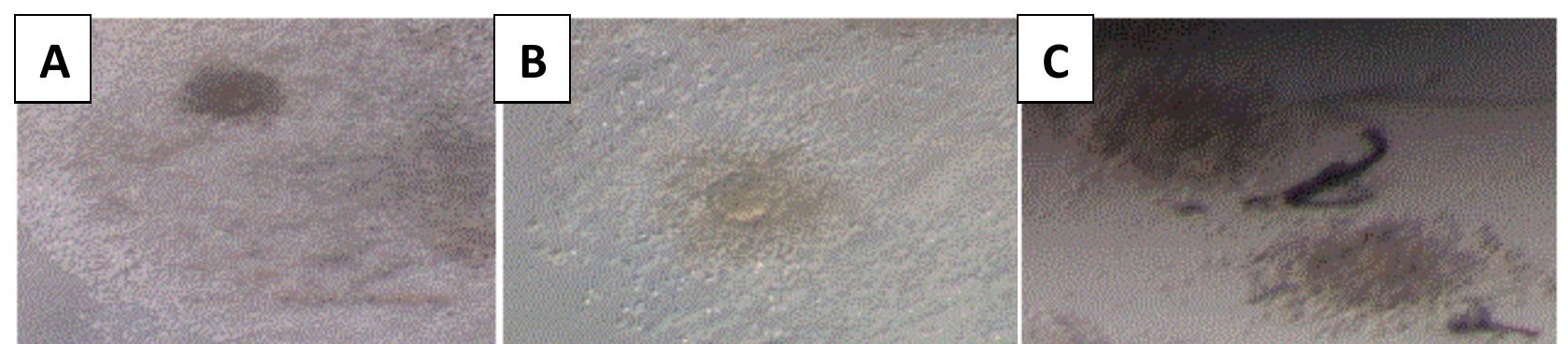


Effect of gonadotrophin dose on oocytes yield and quality and embryonic development...
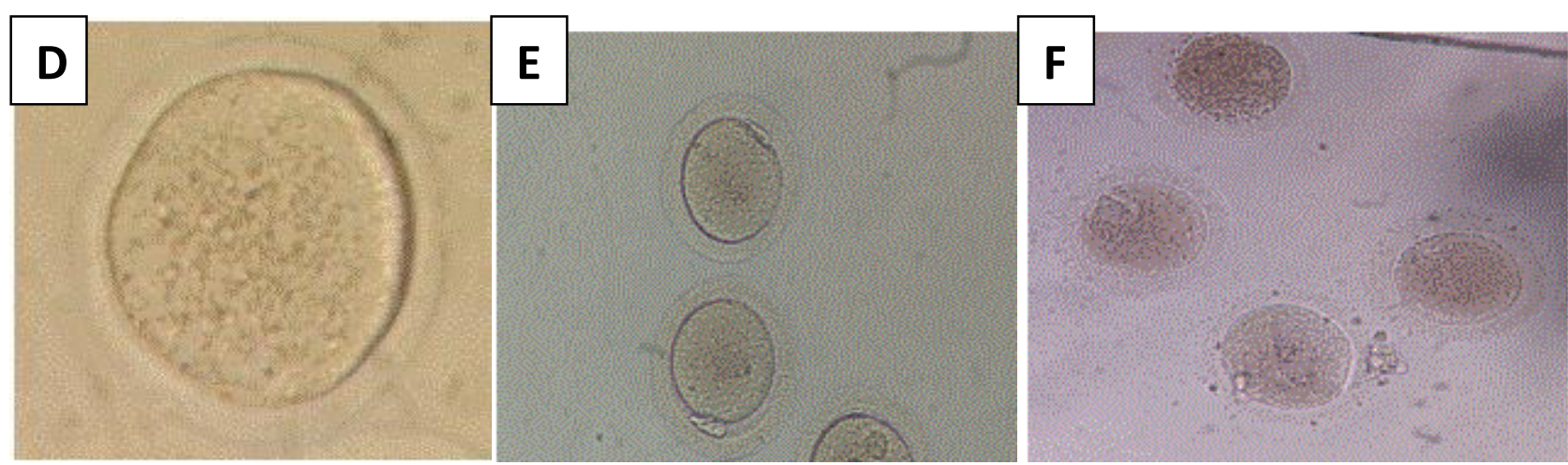

Fig 1: Photograph showing oocyte quality and cumulus cell expansion after collection 40X and 100X Full expansion of COCs surround oocyte which good indicator for oocyte maturity (A 40X, B 100X) C) compacted COCs around oocytes. D) Immature oocytes without polar body MI phase, 400X. E)Mature oocytes with first polar body as an indicator for MII phase200 X.F) Degenerated oocyte200X very dark and granulated cytoplasm.

\section{Embryonic development}

The effect of hMG dose used for induction of superovulation in mice on cleavage rate of in vitro fertilization oocytes and their subsequent embryo development is presented in Table 2. Cleavage rate as indicated by the percentage of IVF oocytes reaching the 2-cell stage was significantly $(\mathrm{P}<0.05)$ higher in group of female mice induced for superovulation by using $15 \mathrm{IU}$

Table 2: Effect of hMG dose used for induction of superovulation on cleavage rate and embryo development rates to the blastocyct stage in mice.
hMG compared with the $20 \mathrm{IU}, 10 \mathrm{IU}$ or $5 \mathrm{IU}$ hMG groups (Fig. 2). There was no significant difference in IVF ratebetween the other doses $(5$ IU, 10 IU or 20 IU hMG).

Embryo development to the 8-cell stage, morula and blastocyst stage was significantly $(\mathrm{P}<0.05)$ higher in mice superovulated using $15 \mathrm{IU}$ hMG than the other doses used for superovulation.

\begin{tabular}{|c|c|c|c|c|c|c|}
\hline \multirow{2}{*}{ HMG dose } & \multirow{2}{*}{$\begin{array}{c}\text { No. Mature } \\
\text { oocytes }\end{array}$} & \multirow{2}{*}{ Cleavage rate $(\%)$} & & \multicolumn{3}{|c|}{ Embryo development rate (\%) } \\
\cline { 4 - 6 } & & & 2-cell & 8-cell & Morula & Blastocyst \\
\hline $5 \mathrm{IU}$ & 135 & $85(62.9 \%)$ & $17(20 \%)$ & $6(7.0 \%)$ & $25(29.4 \%)$ & $37(43.5 \%)$ \\
\hline $10 \mathrm{IU}$ & 329 & $221(67.1 \%)$ & $45(20.4 \%)$ & $21(9.5 \%)$ & $31(14.0 \%)$ & $124(56.1 \%)$ \\
\hline $15 \mathrm{IU}$ & 732 & $623(85.1 \%)^{*}$ & $63(10.1 \%)$ & $54(8.7 \%)^{*}$ & $62(10 \%)^{*}$ & $444(70.7 \%)^{*}$ \\
\hline $20 \mathrm{IU}$ & 692 & $482(69.6 \%)$ & $121(25.1 \%)$ & $43(8.9 \%)$ & $62(13.0 \%)$ & $255(52.9 \%)$ \\
\hline
\end{tabular}

* Significantly differ at $\mathrm{P}<0.05$,

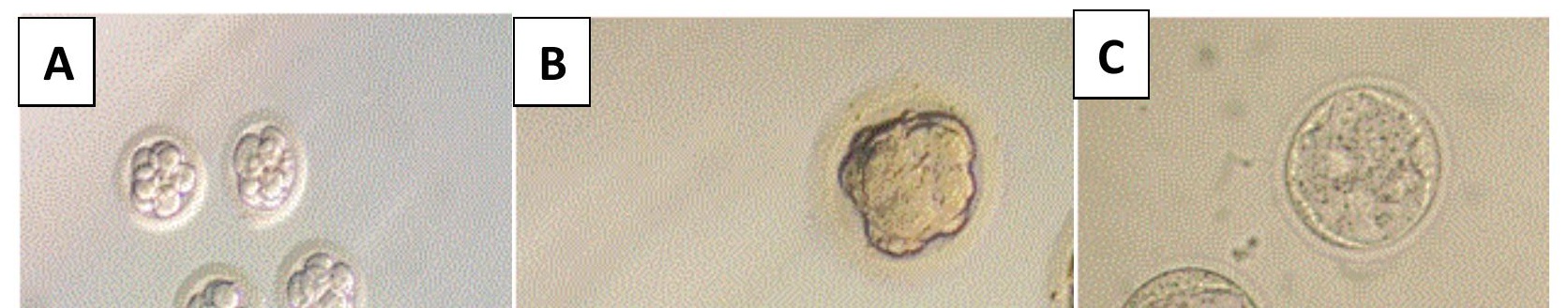


Fig 2: Photograph showing different stages of embryonic development.A) show 8 cell stage (48 hours after in vitro fertilization, 100X). B) show the morula 72 hours after culture, $200 \mathrm{X}$. and C) blastocyst stage (Expanded blastocyst) which obtained after 96 hours from embryo culture some blastocysts started to hatch as a good sign on embryonic development, $200 \mathrm{X}$.

\section{Discussion}

The present study examined the effect of different doses of gonadotropin (5 IU, $10 \mathrm{IU}, 15 \mathrm{IU}$ and 20 IU hMG) used for induction of superovulation on oocytes yield, maturation rate and its effect on embryonic development after in vitro fertilization. In the present work, there was a positive correlation between the number of retrieved oocytes and the hMG dose used for induction of superovulation in female mice. Superovulatory response in terms of number of oocytes recovered was significant $(\mathrm{P}<0.01)$ higher by using $10 \mathrm{IU}, 15 \mathrm{IU}$ and $20 \mathrm{IU}$ hMG compared with the group received $5 \mathrm{IU}$ hMG regimen. Also, a significantly $(\mathrm{P}<0.01)$ higher number of oocytes were collected from group received $20 \mathrm{IU}$ hMG dose than that super ovulated by using $10 \mathrm{IU}$ hMG regimen. Increasing stimulation doses in prepubescent females resulted in an increased number of recovered ova. This results are in accordance with results obtained from prepubescent females with induction doses of 10 and $15 \mathrm{IU}$ of $\mathrm{FSH} / \mathrm{LH}$ $(36.63 \pm 10.14$ and $44.40 \pm 5.00$ oocytes/mouse; respectively) A maximum of 55 ova recovered per mouse was reached when stimulating with 20 IU of FSH/LH. No additional effect was found when using higher stimulation doses, and the number of recovered ova decreased significantly at $25 \mathrm{IU}$ of $\mathrm{FSH} / \mathrm{LH}^{[9]}$. A similar maximum number of 40 to 50 pre-embryos was reached in the study of ${ }^{[16]}$, but reached a plateau at 15 to 30 IU of FSH/LH and decreased with a higher stimulation dose. This wider range of stimulation dose (15 to $30 \mathrm{IU}$ ) resulting in maximal recovery of pre-embryos may be due to the different strain of immature mice (B6D2-F 1) used in this study ${ }^{[16]}$.

In the current study, The same results were obtained in the quality of Cumulus Oocyte Complexes (COCs) which express the quality and maturity of oocytes which showed that there was a very high significant difference between oocytes were obtained after induction with $20 \mathrm{IU}$ and 15 IU higher than 5 IU and 10 IU $(\mathrm{P}<0.001)$ in percentage of full COCs expansion.

Furthermore, in this work, oocytes maturation rate as indicated by the percentage of oocytes reaching M-II stage and extruding the first polar body was significantly $(\mathrm{P}<0.05)$ after induction of superovulation using $15 \mathrm{IU}$ hMG significantly when compared with $5 \mathrm{IU}, 10 \mathrm{IU}$ and $20 \mathrm{IU}$ hMG. Similarly, ${ }^{[9]}$ administration of 20 IU of FSH/LH generated the highest number of oocytes in prepubertal mice, but the ratio of mature oocytes was found to be the highest when this group was induced with $15 \mathrm{IU}$ of FSH/LH. Also, comparable to results at a study by ${ }^{[17]}$ who administered $20 \mathrm{IU}$ of FSH and $10 \mathrm{IU}$ of hCG $(40.90+8.30$ early embryos per mouse). In this 
Effect of gonadotrophin dose on oocytes yield and quality and embryonic development...

study, B6D2-FI (C57BL/6 x DBA/2J) immature female mice were used, and optimal follicular development was obtained with a combination of $20 \mathrm{IU}$ of FSH and 1-10 IU of hCG. Better results with lower doses of hCG than LH, may be due to the potency of hCG which was found to be higher than that of LH.

In addition, the number of degenerated oocytes was significantly $(\mathrm{P}<0.001)$ lower in group of female mice super ovulated by using $15 \mathrm{IU}$ hMG than that treated with $5 \mathrm{IU}$ hMG, $10 \mathrm{IU}$ hMG or $20 \mathrm{IU}$. In previous study, proportions of abnormal (degenerated or parthenogenetic) oocytes were lower with low stimulation doses (10 and 15 IU $\mathrm{FSH} / \mathrm{LH}$ ) in the prepubescent group. However, the lowest proportions were determined in the sexually mature group when stimulated with high doses $(20,25$ and 30 IU FSH/LH). This finding strongly suggests that very high doses of gonadotrophins must be avoided in the prepubescent $\mathrm{BALB} / \mathrm{c}$ mice in order to prevent increased numbers of degenerated/parthenogenetic oocytes ${ }^{[9]}$.

In present study, In vitro fertilization was done for all obtained oocytes from the mice were super ovulated with different doses of U-HMG then the embryonic development was observed for four days after in vitro fertilization, the obtained results show that the fertilization rate of mature oocytes were collected after 15 IU induction was significant higher than fertilization rate of mature oocytes were obtained after induction with 20 $\mathrm{IU}(\mathrm{P}=0.009), 10 \mathrm{IU} \quad(\mathrm{P}=0.0169)$ and $5 \mathrm{IU}$ $+(\mathrm{P}=0.037)$. On other hand there was no significant difference in rate of fertilization of mature oocytes after induction with other doses (5 IU, $10 \mathrm{IU}$ or $15 \mathrm{IU} \mathrm{hMG}$ ).

Furthermore, the present results illustrated that cleavage rate as indicated by the percentage of fertilized oocytes reaching the 2-cell stage was significantly $(\mathrm{P}<0.01)$ for group of mice super ovulated with 15 IU hMG than 5 IU, 10 IU or 20 IU hMG groups. 8 cells stage in all groups. There was significant difference in embryonic development to morula stage between fertilized oocytes were collected from mice that induced with $15 \mathrm{IU}$ more than $20 \mathrm{IU}(\mathrm{P}=0.0328)$ but there was no significant difference between other groups. Also, morula and blastocyst rateswere higher $(\mathrm{P}<0.01)$ for in vitro fertilized oocytes retrieved from $15 \mathrm{IU}$ hMG than the oocytes were collected from mice super ovulated with 5 IU 10 IU or $20 \mathrm{IU}$ hMG.

Increasing stimulation doses of the $\mathrm{FSH} / \mathrm{LH}$ combination resulted in an increased recovery of pre-embryos capable of pre implantation development ${ }^{[16]}$. Expansion of mouse cumulusoocyte complexes in vitro occurs to a degree comparable to that seen in vivo when FSH and LH treatment are used together ${ }^{[18]}$. Also, in vitro role of $\mathrm{LH}$ on the maturation of mouse early follicles ${ }^{[19]}$. Immature mouse oocytes were also shown to mature in medium supplemented with various combinations of $\mathrm{FSH}$ and $\mathrm{LH}^{[20]}$.

All mice received 5 IU of hCG 48 hours after hMG administration, and oocyte retrieval was performed 20 hours post-hCG. During oocyte collection, the oviducts were also flushed after tearing the ampulla, in the case of weak cumulusoocyte complexes which may cause the oocytes to spread in the oviduct. However in all stimulation doses, we could not observe any oocytes from the flushed oviducts. This manipulation led us to rule out the possibility that some mice may have ovulated before the ovulatory hCG treatment ${ }^{[9]}$. Even if FSH alone had been used to induce folliculogenesis, the possibility of early ovulation would again exist, since there are studies determining the potentially important role of FSH in the ovulatory process [21].

The recovery of oocytes 20 hours post-hCG corresponds to postovulatory oocyte recovery 7 to 8 hours. Keeping in mind that mouse oocytes can be fertilized in vivo for about 15 hours postovulation, ovulated oocytes can be fertilized within this 7 to 8 hour period before reaching the end of their life span and hence before postovulatory aging ${ }^{[9]}$. Cytological changes and spontaneous activation may occur in the mouse oocytes as they progressively age in vivo, resulting in an elevated number of abnormal oocytes $^{[22]}$.

Similar results were obtained in present study (Table 1) in which there is high statistical significant difference $\mathrm{P}<0.01$ on number of oocytes obtained after induction with $20 \mathrm{IU}, 15$ IU and 10 IU HMG concentration dose more than induction with 5IU, the number of oocytes were collected after induction with 20 IU dose was significantly higher than $10 \mathrm{IU}$ dose, there was no significant difference in number of oocytes 
between $10 \mathrm{IU}$ and $15 \mathrm{IU}(\mathrm{P}=0.0797)$ or $15 \mathrm{IU}$ and 20 IU doses, but there was no significant difference between 5 IU and 10 IU or 15 IU and $20 \mathrm{IU}$.

Subsequently oocytes maturation showed significant difference after induction with $15 \mathrm{IU}$ more than $20 \mathrm{IU}(\mathrm{P}=0.0323)$ and very high significant difference $(\mathrm{P}<0.001)$ more than $5 \mathrm{IU}$ and $10 \mathrm{IU}$ also $20 \mathrm{IU}$ dose gave maturation rate significantly higher than $5 \mathrm{IU}$ and $10 \mathrm{IU}$ $(\mathrm{P}<0.001)$ but oocytes maturation rate was not significant after induction with $5 \mathrm{IU}$ or $10 \mathrm{IU}$ doses $(\mathrm{P}=0.571)$. [16[found that stimulation of immature females with $5 \mathrm{IU}$ of $\mathrm{FSH} / \mathrm{LH}$ resulted in recovery of fertilized oocytes in $64 \%$ of mice. In present study, In vitro fertilization was done for all obtained oocytes from the mice were super ovulated with different doses of U-HMG then the embryonic development was observed for four days after in vitro fertilization, the obtained results showed that the fertilization rate of mature oocytes were collected after 15 IU induction was significant higher than fertilization rate of mature oocytes were obtained after induction with 20 $\mathrm{IU}(\mathrm{P}=0.009), 10 \mathrm{IU} \quad(\mathrm{P}=0.0169)$ and $5 \mathrm{IU}$ $(\mathrm{P}=0.037)$. On other hand there was no significant difference in rate of fertilization of mature oocytes after induction with other doses (5 IU, 10 IU or $15 \mathrm{IU})$.

The evaluation of embryos for their in vitro survival capacity and their ability to generate ESlike cells demonstrate that the embryos derived from rats treated with the highest dose of PMSG had a lower capacity to survive in culture and to form ES-like cell colonies than those embryos obtained from rats treated with the lower ${ }^{[2]}$.

That agrees with the obtained result from present study which illustrated that there was no significant difference in development rate of fertilized oocytes to 8 cells stage in all groups. There was significant difference in embryonic development to morula stage between fertilized oocytes were collected from mice that induced with 15 IU more than 20 IU ( $\mathrm{P}=0.0328)$ but there was no significant difference between other groups. Blastolation rate in fertilized oocytes were collected from mice that induced with $15 \mathrm{IU}$ U-HMG was significantly more than the oocytes were collected after super ovulation with $5 \mathrm{IU}$ $(\mathrm{P}=0.01796)$ and significantly higher $(\mathrm{P}=0.0034)$ than oocytes which collected from female mice were super ovulated with $20 \mathrm{IU}$.

This situation would be anticipated in association with excessive gonadotropin stimulation, which has been reported to resultin impaired embryo growth in the rat ${ }^{[23]}$, mouse ${ }^{[24]}$, human ${ }^{[25]}$, and sheep ${ }^{[26]}$, where a typical gonadotropin levels ${ }^{[27]}$ resulting in a nomalies of oocyte maturation [28] have been implicated. More specifically, a reduced rate of oocyte fertilization has been reported in IVF patients with raised basal levels of serum luteinizing hormone (LH)during the follicular phase, with premature oocyte maturation being proposed as a possible mechanism for this effect ${ }^{[29]}$. Since both PMSG and hMG preparations contain significant LH activity, the administration of excessive levels of either may result in raised basal LH levels during follicular development. Increasing the tonic level of LH by gonadotropin stimulation late in the follicular phase may be particularly detrimental since it has been reported that high tonic levels of urinary LH in the late follicular phase are associated with a lower incidence of establishment of pregnancy and an increased rate of abortion following IVF-ET ${ }^{[30]}$.Conclusion: From the previous study the obtained results prove that using dose of $15 \mathrm{IU}$ hMG for induction of superovulation Balb/c mice give best results in terms of number of retrieved oocytes, highest percentage with cumulus cell expansion, cleavage rate and embryo development to the blastocyst stage.

\section{Ethical approval}

This study was reviewed and approved by the Ethical Committee of Faculty of Science, AlAzhar University, and the Ethical Committee of Nuclear Materials Authority.

\section{Conflict of interest}

Authors declare that there is no conflict of interest.

\section{References}

1-Cornejo-Corte's MA, Sánchez-Torres C, Va'zquez-Chagoya' JC, Sua'rez-Go'mez HM, Garrido-Farin $G$ and Meraz-Rı'os MA (2006):Rat embryo quality and production 
efficiency are dependent on gonadotrophin dose in superovulatory treatments. Lab. Anim..,40: 8795.

2-Santiago-Moreno J, Gonzalez-Bulnes A and Gomez- Brunet A (2001): Procedure for successful interspecific embryo transfer from mouflon (Ovis gmelini musimon) to Spanish merino sheep (Ovis aries). J. Zoo and W.L. Med..,32:336-341.

3-Eistetter HR (1989):Pluripotent embryonal stem cell lines can be established from disaggregated mouse morulae. Develop. Grow. \& Differ., 31: 275-282.

4-Auerbach AB, Norinsky $R$ and Ho W (2003): Straindependent differences in the efficiency of transgenic mouse production. Transgenic Research, 12: 59-69

5-Charreau B, Tesson L, Soulillou JP, Pourcel $C$ and Anegon I (1996): Transgenic in rats: technical aspects and models. Trans. Resea..,5: 223-234.

6-Cuello C, Berthelot $F$ and Martinat-Botte F (2004): Transfer of vitrified blastocysts from one or two superovulated large white hyperprolific donors to Meishan recipients: reproductive parameters at day 30 of pregnancy. Therio., 61: 843-50.

7-Kanitz W, Becker F and Schneider F (2002): Superovulation in cattle: practical aspects of gonadotrophin treatment and insemination. Reproduction Nutrition Development,42; 587-99 8-Graff KJ, Meintjes $M$ and Han $Y$ (2000):Comparing follicle stimulating hormone from two commercial sources for oocyte production from out-of-season dairy goats. Jour. Dai. Sci., 83: 484-7.

9-Ozgunen T.K., Erdogan S., Mazmanoglu N., Pamuk I, Logoglu G. and Ozgunen T (2001): Effect of gonadotropin dose on oocytes retrieval in superovulated Balb/C mice. Therio., 56:435445.

10-Legge $M$ and Sellens MH (1994): Optimization of superovulation in the reproductively mature mouse. J. Assis. Reprod. and Gene, 11:312-318.

11-Munoz I, Jesus DNA, Josa A, Espinosa E and Gil I (1995): Use of follicle-stimulating hormone (FSH) to increase the in vitro fertilization (IVF) efficiency of mice. J. Assis. Reprod. and Gene, 12:738-743.
12-Rugh R (1968): The mouse: its reproduction and development. Burgess Publishing Co, USA. https :// www.cabdirect.org / cabdirect / mobile I abstract /19690101113

13-Munoz I, Rodriguez de Sadia C, Gutierrez A, Blanquez MJ and Pintado B(1994): Comparison of superovulatory response of mature outbred mice treated with FSH or PMSG and development potential of embryos produced. Therio., 41:907-914.

14-Hogan B, Constantini F and Lacy E (1986): Manipulating the mouse embryo. Cold Spring Harbor Laboratory, USA. https://www.cshlpress.com/default.tpl?car $\mathrm{t}=1542268892245197996 \&$ fromlink=T\&linkacti on=full\&linksortby=oop_title \&--

eqSKUdatarq $=982$

15-Licht P, Gallo AB, Aggarwal BB, Farmer SW, Castelino JB and Papkoff $H$ (1979): Biological and binding activities of equine pituitary gonadotrophins and pregnant mare serum gonadotrophin. J. Endoc., 83:311-322.

16-Ziebe S, Guoliang $X$ and Byskov AG (1993): Impact of gonadotrophin dose on preembryo recovery and development in superovulated mice. Hum. Reprod.,8:38.

17-Andersen CY, Ziebe S, Guoliang $X$ and Byskov AG (1999): Requirements for human chorionic gonadotropin and recombinant human luteinizing hormone for follicular development and maturation. J. Assis. Reprod. and Gene, 16: 425-430.

18-Chen L, Russell PT and Larsen WI (1994): Sequential effects of follicle-stimulated hormone and luteinizing hormone on mouse cumulus expansion in vitro. Biolo. Reprod., 51: 290-295.

19-Cortvrindt R, Hu $Y$ and Smitz J (1998):Recombinant luteinizing hormone as a survival and differentiation factor increases oocyte maturation in recombinant follicle stimulating hormone supplemented mouse preantral follicle culture. Hum. Reprod.,13: 12921302 .

20-Jirmo M, Sandow BA and Hodgen GD (1990): Full physiological maturation in vitro of immature mouse oocytes induced by sequential treatment with follicle-stimulating hormone and luteinizing hormone. J In Vitro Fertili. Embr. Trans., 5: 285-291. 
21-Montgomery Rice VC, Zusmanis K, Malter $H$ and Mitchell-Leef D (1993): Pure FSH alone induces ovulation and subsequent pregnancy in the mouse resulting in fetal development. Lif. Sci., 53:31-39.

22-Mailhes JB, Young D and London SN (1998):Postovulatory ageing of mouse oocytes in vitro and premature centromere separation and aneuploidy. Biolo. Reprod.,58:1206-1210.

23-Walton EA, Evans G and Armstrong DT (1983): Ovulation response and fertilization failure in immature rats induced to superovulate. J. Reprod. Fertil.,67:91-96.

24-Sato F and Marts RP (1986): The effect of pregnant mare serum gonadotropin on mouse embryos fertilized in vivo or in vitro. $J$ In Vitro Fertili. and Embr. Trans., 3:353-357.

25-Lopata A (1983): Concepts in human in vitro fertilization and embryo transfer. Fertili. Sterili.,40:289-301.
26-Moor RM and Trounson AO (1977):Hormonal and follicular factors affecting maturation of sheep oocytes in vitro and their subsequent developmental capacity. J.Reprod. Fertili.,49: 101-109. 27-Osborn JC and Moor RM (1985):Oocyte maturation and developmental competence. In: In Vitro Fertilization and Donor Insemination, Proceedings of the Twelfth Study Group of the Royal College of Obstetricians and Gynaecologists, W Thompson, DN Joyce, JR Newton (eds). London, Royal College of Obstet. Gynaecolo., pp 101-114

28- Moor RM, Osborn JC and Crosby IM (1985): Gonadotrophin-induced abnormalities in sheep oocytes after superovulation. J. Reprod. Fertili.,74:167-172.

29-Stanger JD and Yovich JL (1985): Reduced in-vitro fertilization of human oocytes from patients with raised basal luteinizing hormone levels during the follicular phase. B. J. Obstet. Gynaeco., 92: 385-393.

30-Howles CM, MacNamee MC, Edwards RG, Goswamy R and Steptoe PC (1985):Effects of high tonic levels of luteinising hormone on outcome of in-vitro fertilisation. Lancet., 2:521522. 